811.163.41'282.2(497.6-15)

811.163.41'342.41(497.6-15)

https://doi.org/10.18485/sj.2018.23.1.29

ДРАГОМИР В. КОЗОМАРА*

Универзитет у Бањалуци

Филолошки факултет
Оригинални научни рад

Примљен: 04. 01. 2018.

Прихваћен: 29. 01. 2018.

\title{
СУДБИНА ВОКАЛСКИХ СКУПИНА У ГОВОРУ БАСТАСА (КОД БОСАНСКОГ ГРАХОВА)
}

\begin{abstract}
На основу релевантних примјера, у овом раду првенствено се сагледавају начини неутралисања појединих вокалских скупина у говору Срба једног босанскограховског села. Рад има циљ да се прикаже судбина вокалских скупина у истраженом пункту и, на основу постојеће литературе, одреди његово мјесто у западнобосанским српским говорима као цјелини.

Кључне ријечи: вокалске скупине, сажимање (контракција) вокалских скупина, неутралисање вокалских скупина, српски ијекавски говори западне Босне, источнохерцеговачки (херцеговачко-крајишки) дијалекат.
\end{abstract}

\section{I. УВОДНЕ НАПОМЕНЕ}

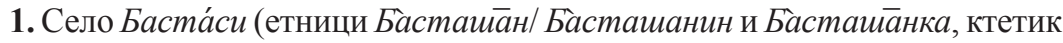
баста̄ $\bar{\kappa} \bar{u})$ налази се у доњем Ливањском пољу, на тромеђи ливањске, граховске и гламочке општине, а административно припада граховској општини. Смјештено је у подножју планине Старетине, отприлике на половини пута између Ливна и Босанског Грахова, на око 750 метара надморске висине. Простире се на дужини од приближно седам километара - на западу се граничи са граховским селом Нуглашицом, а на истоку са Богдашима, који припадају ливањској општини.

*dragomir.kozomara@flf.unibl.org 
До краја 1994. године у Бастасима је у око 65 породица живјело отприлике 170 становника, искључиво православне вјероисповијести. Због ратних збивања, крајем 1994. године комплетно становништво било је расељено, а куће готово у потпуности уништене. Послије потписивања Дејтонског мировног споразума мањи дио предратних становника уз помоћ међународне заједнице обновио је имовину и вратио се у Бастасе. С обзиром на то да је повратничко становништво углавном старије животне доби, природна селекција учинила је своје, тако да данас у селу живи свега петнаестак становника.

2. Становништво Бастаса веома мало зна о свом поријеклу. Већина о том не зна готово ништа, а они који нешто „знају” о својим коријенима, углавном кажу да су се доселили „из Да̀лма̄нције”. И М. Петрић (Петрић 1961: 37) у дијелу рада у којем говори о поријеклу становништва доњег Ливањског поља констатује да је више од половине Срба ијекаваца поријеклом из Далмације. Помињући Бастасе, исти аутор наводи и сљедеће: „Seljaci pričaju da je selo dobilo naziv po potoku Bastašici, a i po tome 'što je ovdje bila nekakva rimska vojska koja se zvala Bas'. U selu, na mjestu zvanom Crkvina, otkopano je nekoliko fragmenata rimskih nadgrobnih spomenika. Ima i srednjovjekovnih nadgrobnih spomenika; svi su bez natpisa i ornamentike. Po svemu sudeći, ovdje je postojalo jedno staro naselje" (Петрић 1961a: 72). На истом мјесту Петрић је навео тадашње родове који су живјели у Бастасима, њихово поријекло и крсну славу.

3. Према општој класификацији (в. Драгичевић 1986: 226-228, Ивић 1996: 146 и Драгичевић 2001: 86-87) говор Бастаса по својим особинама припада источној скупини сјеверозападног огранка источнохерцеговачког (херцеговачко-крајишког) дијалекта. Овај говор до сада није био предмет обимнијих дијалектолошких радова. Скромни прилози аутора овог рада: необјављени дипломски рад Фонетске особине говора села Бастаса (Козомара 2000), Млинарска терминологија Бастаса (Козомара 2002), те прије двадесетак година попуњен упитник приликом прикупљања дијалекатске грађе за потребе израде Српског дијалектолошког атласа - једини су радови који су за тему имали искључиво говор Бастаса. Проф. Н. Рамић, изучавајући јатовску проблематику у говорима југозападне Босне, дио дијалекатске грађе узео је и из говора Бастаса, који су му, између осталих, били један од пунктова истраживаног ареала (обједињене радове в. у Рамић 2010). Проф. М. Дешић у студији о западнобосанским ијекавским говорима (Дешић 1976) допирао је до Бастасима сусједне Нуглашице. У вези са говором Бастаса треба поменути и рад Ђ. Чустовић о говору становништва Ливањског поља (Чустовић 1961), гдје је нешто података (не баш поузданих) дато и о говорним особинама Срба ијекаваца. У оквиру дијалекатских истраживања говора̄ централне, југоисточне и југозападне Босне (БХДЗб 1990) Бастаси се нису нашли на списку пунктова, а најближе истражени пунктови српских говора били су већ помињано сусједно село Нуглашица и ливањско село Бојмунте, које је од Бастаса удаљено десетак 
километара источно према Ливну. И за податке који су се тамо нашли мора се рећи да су готово неупотребљиви ${ }^{1}$.

4. Свестраније изучавање српских ијекавских говора западне Босне започето је монографијом о змијањском говору (Петровић 1973). Три године касније објављена је најобимнија и засад непревазиђена студија о западнобосанским ијекавским говорима (Дешић 1976). Послије двадесетак година описани су ијекавски поткозарски говори (Далмација 1997). Слика о говорном стању у српским западнобосанским говорима касније је у неколико наврата употпуњавана краћим радовима, а они релевантнији за овај рад биће и овдје поменути. Сагледавањем општег стања у наведеним и још неким другим радовима, на основу прикупљене дијалекатске грађе овдје ће се приказати судбина вокалских скупина (прије свега њихово сажимање) у говору Бастаса и на основу тога одредити његово мјесто у укупности српских западнобосанских говора.

\section{II. ГРАЂА}

5. У облицима неколико именица, те глагола јахати скупина $a a<a x a$ сажима се у једно дуго $a$ : ѝзијо дваิ тањи́ра гpâ, не̂ма̄ грâ оेвок љёта; јѐдан câm,

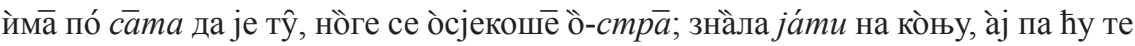
по̀ја̄mи на ма̀га̄рцу, ӱзза̄ла на́ њу, у̀зјатти на ма̀гаре.

Група $a a<$ aja такође се сажима у $\bar{a}$ у формама глагола стајати: ста́ла сву̀ но̄ћ, ста́ле до Лије́вна, нѐ море ста́ти на но̀гами.

У бројевима од `11 до `19 неакцентована медијална група ае редовно се

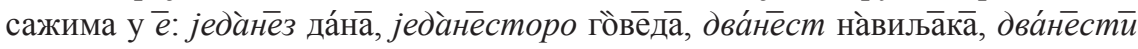
да̂н да̀нас, три́несторо чёља̄ди, четрунест вӧло̄ва̄, петне́стак му да́на, ѝма̄ шееснест у̀лйшта̄, оса̀мнест ми гӧдйна̄ би́ло, деветтнестии маัј и сл.

У упрошћеном облику броја двадесет ова скупина је акцентована и сачувана: два̀ест или се неутралише слабим прелазним гласом $j$ : два̀'ecm.

Чува се и онда кад се формира након губљења позиционо нестабилног сугласника $j$ : вйё (= увијек) се сјётимм, у то̀плё кра̀еве, ла̀а сву̀ но̄ћ, $\grave{y} \partial \bar{a} e$ ће̂р итд.

У облицима именица аеродром и аероплан иницијална секвенца ае упрошћава се неутралисањем првог дијела секвенце: йде на ёродромм, ёно ёропла̄на.

\footnotetext{
${ }^{1}$ Аутор овог рада рођен је у Бастасима и веома добро му је познат говор Срба доњег Ливањског поља. Због очигледних грешака присутних у два посљедња наведена рада - у даљој анализи неће се више ни помињати.
} 
У сантхијским везама скупина $a$-e која настаје након губљења интервокалног $j$ из енклитике је понекад се сажима у $\bar{a}$, али много чешће остаје несажета:

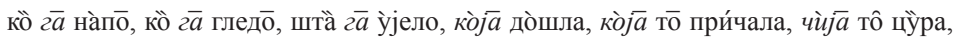
чѝja зѐмља, тӧга̄ и тра́ва;

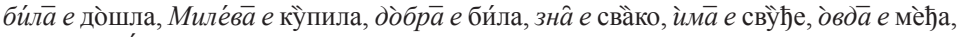

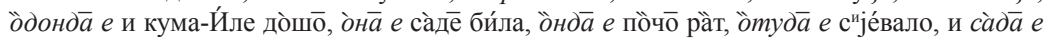

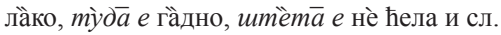

Финална скупина $а о><$ сл која није акцентована обично се сажима у $\bar{o}$. Ова промјена најчешће се огледа у ликовима глаголског придјева радног и потврђена је мноштвом примјера:

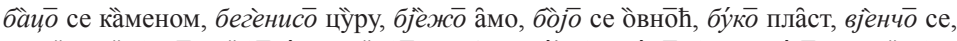

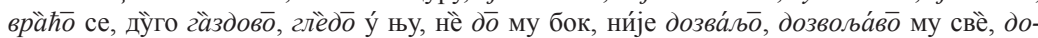
чеки́во је, дўгово ми пйћу (= сијено), жва́ко коेр"цу, Јо́во за̀пуцо̆, засу́ко рука́ве, зймово̄

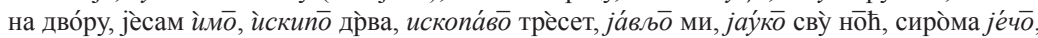
кази́во нам, ка́зо њоิјзи, капа̀рисо й Ма́те, Јо̀ја ко̀во но́же, ко̀по испо̀т куће, ку̀ेво се ку̀пус,

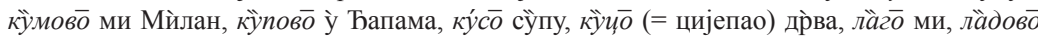

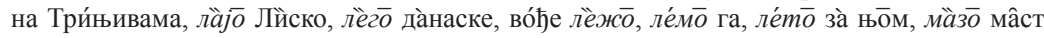

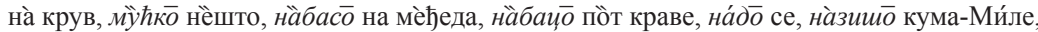

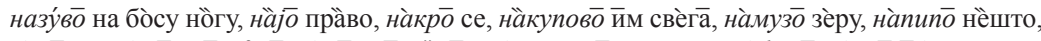

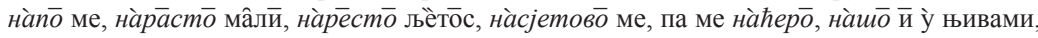

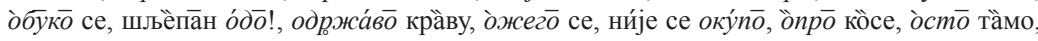

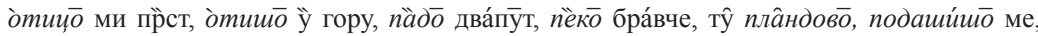

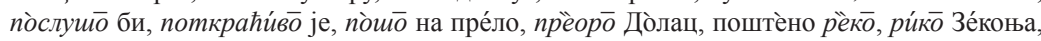

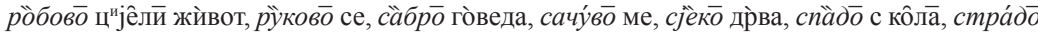

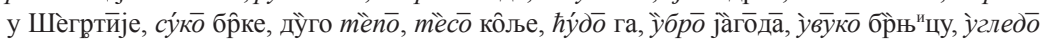

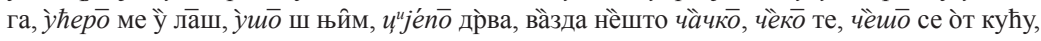

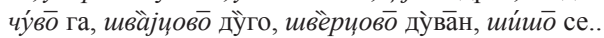

Акцентоване скупине некад се чувају: брӓо дре́њке, свё му дӑо, звӓо

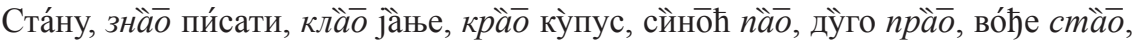
или се сажимају у $\bar{a}$ : бра̂ тйкве, свё му је $\partial \hat{a}$, нѐ зна̄м ка̀ко се̄ зва̂, ни́је зна̂, кла̂ пйла̄т, кра̂ бру̀сове, јоेпёт $n \hat{a}$, ни́је се $n p \hat{a}$, штоे си $c m \hat{a}^{2}$.

Финална скупина $a о$ сажима се у $\bar{o}$ и у ограниченом броју именица: ѝмала

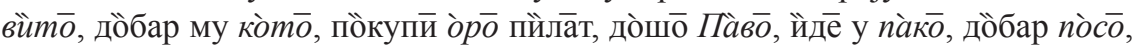

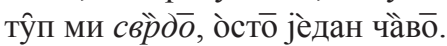

Контракција завршне секвенце ао спроводи се и у придјеву округао: праัво окри́zо, окру́zо у ли́цу и сл.

${ }^{2}$ Типове оваквог сажимања налазимо само код Дешића (Дешић 1976: 73-74), и то тамо гдје су навођени примјери за зону $-\bar{a}$ (о зони $-\bar{a}$ и $-\bar{o}$ в. у т. 11). Овакви примјери сажимања често се могу чути и у говору Срба из осталих села доњег Ливањског поља, а биљежени су и у говору требавских Срба (Драгичевић 2002: 206), што значи да они нису посебна специфичност говора Бастаса као зоне $-\bar{o}$, те да појаву треба додатно истражити. 
За прилог жао правило је као за придјеве типа брао - група ао остаје несажета: жаั̄o ми је, би́ло йм жаั̆ и др., или се сажима у $\bar{a}$ : вӑзда ми жа̂, жа̂ ми га̄ је итд.

Медијална скупина $a о$ зна за сажимање у $\bar{a}$ без обзира на то да ли је акцентована или не: остала жаิвииа, ѝзвади жа̂вииу, мо̀ја заิва, Мйлкино̄ј за̂ви,

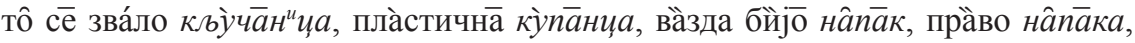
на̂па̄ко му би́ло, дрेвенё са̂не, дјѐчињё са́н"üe.

Контраховање у $\bar{o}$ спроводи се у облицима именице умиваоник: нӑпољу је умиво́нйк, ёно сапу́на на умиво́нику.

Медијална секвенца $а о>о$ у ликовима именице саобраћаj: злӧ је та̂j сӧбраћа̄j, гйнё се у сӧбраћајjy .

Скупина ао $<$ ахо сажима се у $\bar{a}$ у облицима именице Грахово и њеним

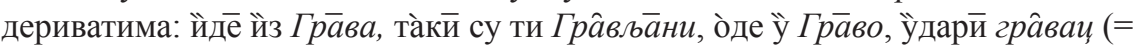
врста вјетра), граิвскй ло́пови.

Сасвим је обично: нӑорма̄лан, наиорма̄лна, найома̄лно

Везник као обично се јавља у облику ко, при чему је ово $о$ редовно кратко: све́дно ко да глёда̄ш, йде̄ ко мо̀мак, пу̀че ко пу̀шка, ко ѝ тй, ко да би ме пи́то, пјёва̄ ко сла̀вӯj5.

У посебним говорним ситуацијама умјесто као $и$ може се чути кај и

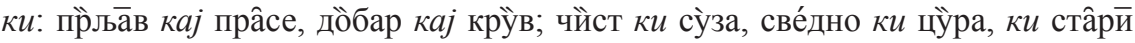
ста̀рац 6 .

Група -ау- контрахује се у $\bar{a}$ у формама глагола упаучити се: уेпа̄чила се сва̀, у̀папчило се браัшно.

Редовно је зувар (< за ухар): зу̀вар би би́ло, зу̀вар ти је ѝ то и сл.

Почетна скупина ay неутралише се у облицима именице аутобус и

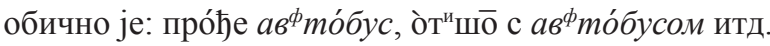

6. Група -ее- <-еје- обавезно се контрахује у $\bar{e}$ у прилогу свеједно: мёни је све́дно, све́дно ко да глёда̄ш, нё би му све́дно и сл.

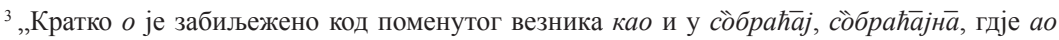
није било на апсолутном крају ријечи (као што је то случај са већином осталих примјера) и гдје је $a$ било под акцентом" (Дешић 1976: 78).

${ }^{4}$ Тако је и у ливањско-дувањском говорном типу (Рамић 1999: 304).

5 „За ко претпостављамо да је добијено контракцијом, уз накнадно скраћивање вокала $o$ ” (Николић 1991: 215).

${ }^{6}$ Везник ки познат је низу других говора. О тумачењима његовог поријекла в. у Дешић 1976: 80 и литератури на коју је тамо упутио. У Дешићевој грађи нема потврда за облик везника

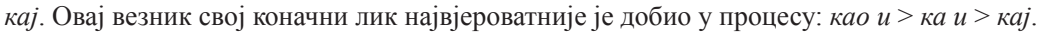


Сантхијска скупина $e$-e формирана након елиминисања сонанта $j$ из енклитике је зна и за сажимање и за чување:

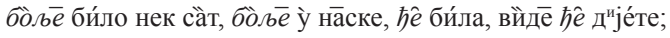

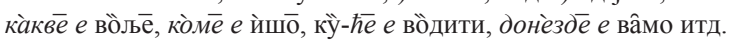

Неакцентована финална скупина -ео <-ел у радном глаголском придјеву најчешће се своди на -о̃:

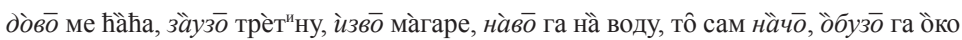

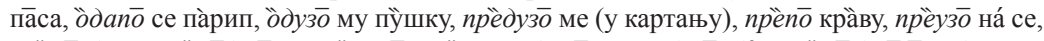

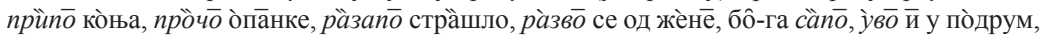
уेзо њйву поัполи итд.

У неким случајевима ова скупина остаје сачувана: за̀мео сније̂к, на̀вео га на тӑнак леิд $д^{\mathrm{T}}$ о̀плео крошњу, по̀мео испо̀т кра̄ва̄.

Чува се и кад је акцентована: жёео жйто, клё̄о у̀ дрво, у̀ каме̄н, плё̄ крेто, свёо̄ ме до̀ куће̄.

Сажимање скупине -ео > -о спроводи се и код неких именица и придјева:

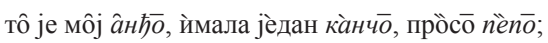

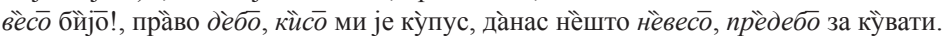

Секвенца -ео- потпуно се неутралише у облицима именице метеоролог:

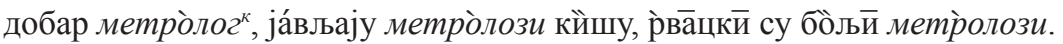

Неутралисање вокала $y$ из групе еу- забиљежено је у лексеми еурокрем: воัлй ёрокрем м, на̀мажи ёрокремма7.

7. Скупина $и$, која се често (не и обавезно) формира након губљења

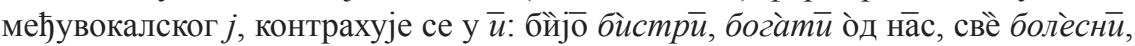

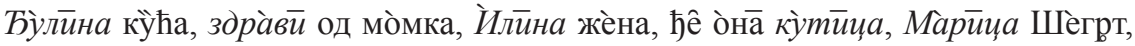
ни́сам нйчй, за̀падоше га но̀вй оेпа̄нци, палетннй оेд мене, Дрӓгица Перйна, бйјо

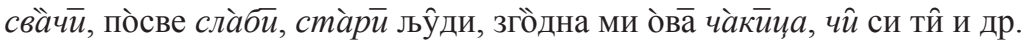

Група -ио <-ил у облицима глаголског придјева радног најчешће се укида интерполацијом сонанта $j$ :

бйjo ácn, бра́нијо се, бу́нијо се, вӑдијо меда, вйдијо Уро̀ша, да̀наске се вра́тијо,

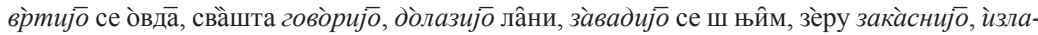
зијо у Гори"цу, йзлијо плоัчу, jáвијо да је стйго, коेсијо у Шѐгртйје, крेстијо га по̆п Шѐшум, ку́nијо маิсти, ни́је мйслијо, нава́лијо йћи, напа́лијо чёлу, но̀сијо пи́смо, нйшта ни́је о̀кусијо, о̀пазијо се жѐнити, свё осттавијо, ва̀зда се пӓтијо, примшијо му у̀з уши, ра́дијо у Лије́вну, ро̀дијо се, руїиијо зитт, саивијо тру́бу, са̀млијо код Јанека, свйтијо га (= погодио) ка̀меном, со̆чијо га (= спазио, примијетио) у̀ Ждра̄ло̄вцу, тёглијо ко си́воња, ту́жијо га, уубијо бӧга у̀ њему, икопијо праัса̄т и сл.

${ }^{7}$ Именица ёрокре $м$, те већ поменуте именице ёродром м и ёропла̄н највјероватније су настале обичним неутралисањем једног дијела вокалске секвенце, а не њеним сажимањем и накнадним краћењем. На овакву претпоставку наводи чињеница да су ово ријетко фреквентне групе, те и не постоје устаљени модели за њихово сажимање. 
Овакво $j$ понекад има слабију артикулацију:

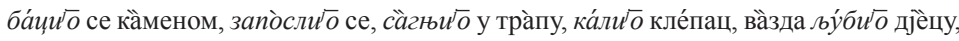

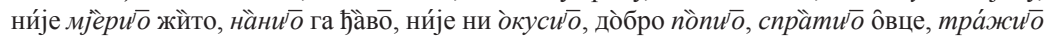
цивйка̄т ${ }^{8}$.

Према инфинитиву глагола бољети радни глаголски придјев гласи болијо или бӧљьо: болијо га дроิп; бо̀љ $\bar{o}$ га зўп и сл.

8. Вокалска секвенца -оa- редовно се сажима у $\bar{a}$ у облицима именице

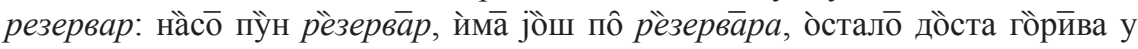
рёзервару.

Такву судбину има и скупина -оа- која води поријекло од -оја- из форме именице појас: стаัвй пиेшто̄љ за̀ $n \bar{a} c$, во̀да до̆ $n \bar{a} c a$, дрџжй ноิж за̀ $n \bar{a} c o м$.

Обично је чоั่ек, чо̆ंека, чо̆ंеку..., а понекад се након неутралисања међувокалског $j$ група ое контрахује у $\bar{e}$ : зна̂ че̂к, пйта̄j че́ка, рѐци че́ку.

Група оо < ол контрахује се у $\bar{o}$ : бô се с во̀лом, гоิ ко оेд мајке рӧђен, о̀де у̀ До, Коза́рове ко̀коши у До́иy, ђа̀во га доेнесе, збô га но́жом, спуิшта̄ се на ко́иy,

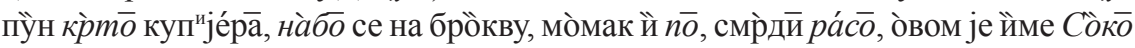
(име коња), нӧвй стоे, то̂ ти је сто̆Ђаво, сјѐдй на сто́иy, у̀бо се у̀ прст.

Сажимање секвенце -оо- (<-охо-) у дуго -о- спроводи се у облику именице походи: о̀де у̀ по̆де, доेшо ӱ по̆де и сл.

9. Финална секвенца уо < ул (као и скупуне $а о, е о$ ) најчешће се контраxyje y $\bar{o}$ :

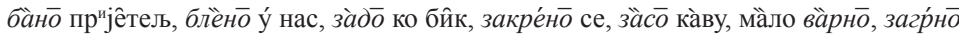

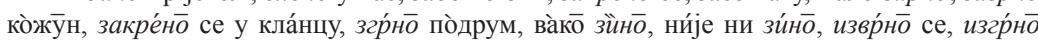

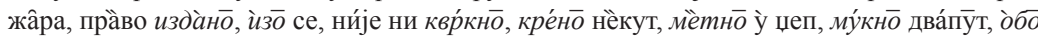

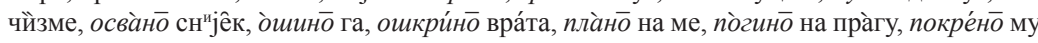

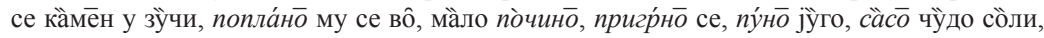

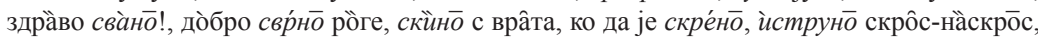
тоि је оิн су́кно, шйтнно лӧпту.

Присутни су и аналошки облици типа: замије́но за ра̀кију, размије́но га Бра̂нко, смијје́но га, учѝно му се (исп.: Дешић 1976: 90).

Акцентована финална скупина уо, забиљежена само у облику чуо, понекад се чува: ч⿱亠䒑̄o сам те, ни́је чіӯ и сл., или се и она сажима у $\bar{o}$ : то̂ сам да́вно чô, је-ш чоิ да је Ми́ле доेшо̄ итд.

Скупина уо < ухо разбија се гласом в у именици ухор: црвѐни јој се у̀вор не̂ма̄ по $\bar{y} в о р а$, а чува се у творбеним облицима типа: вйди што сё зауо́ријо, зауо́р ${ }^{u} л а$ се оेна̄ пйл ца.

${ }^{8}$ О гласу $j$ који неутралише скупину ио в. Ивић 1966: 115. 
Медијална група $y o$ контрахује се у $\bar{o}$ у форми именице Духови, која се јавља у два различита морфолошка облика: сутра Довве, за̀ трй даิна Дови.

10. Остале скупине добро се чувају - како оне које су акцентоване, тако и оне које се налазе на границама твореница, што се види на основу неколико сљедећих, произвољно одабраних примјера:

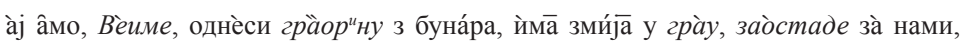
наобла́чило се, но̆сй нӑоча̄ле, вёћ ѝма̄ на̀усний, доेбро нау̀чијо, поа́сијо се, по̆узак му

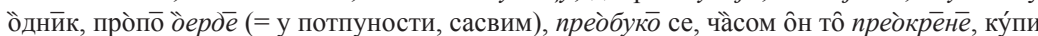

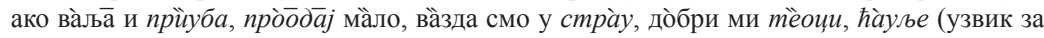
тјерање говеда) итд.

\section{III. ЗАКљУЧНЕ НАПОМЕНЕ}

11. Судбина финалних вокалских скупина у облицима радног глаголског придјева, као најзаступљеније морфолошке категорије по броју наведених примјера, представља добру полазну основу за смјештање говора Бастаса у корпус српских говора западне Босне као веће говорне цјелине. Сагледавањем укупног стања на територији коју захватају српски западнобосански говори, долазимо до закључка да је судбина финалних неакцентованих вокалских секвенци ао у глаголском придјеву радном поуздана изоглоса на основу које може да се класификује ово говорно подручје. На основу оваквог критеријума, српски говори западне Босне раздвајају се у двије зоне - зону $-\bar{a}$ (дио Босанске Крајине у којем се секвенца -ао своди на $-\bar{a}-$ в. Дешић $1976: 73-75)$ и зону $-\bar{o}$ (преостала територија, гдје -ao >-o- -исп.: Петровић 1973: 59-60, Дешић 1976: 76-90, Далмација 1997: 32-35, Драгичевић 2000: 18-19, Црњак-Козомара 2015, 704-705). Као што се види према екцерпираној грађи, говор Бастаса припада већем ареалу - зони - $\bar{o}$, што је и потврђено низом примјера у т. $\mathbf{5}$.

Скоро редовно контраховање неакцентованих секвенци -ео, -уо у -о у облицима радног глаголског придјева потврђује компактност говора Бастаса са свим осталим српским говорима западне Босне. Ако се изузме слушни утисак истраживача, и скупина -ио у облицима глаголског придјева радног у говору Бастаса у суштини има исту судбину као и у свим другим западнобосанским говорима.

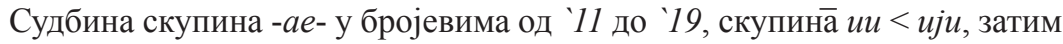
скупина $о о<$ ол, те судбина већине различитих скупина насталих у сантхију - још је једна већа група наведених примјера који потврђују несумњиву припадност говора Бастаса говорима ширега српскога говорног простора на подручју западне Босне. У изнесеној грађи подударност је видљива и у мноштву других појединости. 
Нешто изолованих случајева који се не слажу са укупним стањем у другим истраженим говорима редовна су појава која се јавља у оваквим типовима истраживања и која налаже додатна истраживања, што ће веома брзо бити и учињено у радовима који слиједе.

\section{IV. ЛИТЕРАТУРА}

БХДЗб 1990: Говори цеентралне, југоисточне и југозападне Босне, Bosanskohercegovački dijalektološki zbornik VI, Institut za jezik i književnost u Sarajevu - Institut za jezik, Sarajevo, 1-358 (дио грађе коју je обрадио Д. Вујичић, 7- 124).

Далмација 1997: С. Далмација, Ијекавски говори Поткозарја, Бањалука, $1-264$.

Дешић 1976: М. Дешић, Западнобосански ијекавски говори, Српски дијалектолошки зборник XXI, Београд, 1-316 + карте.

Драгичевић 1986: М. Драгичевић, Говор личких јекаваия, Српски дијалектолошки зборник XXXII, Београд, 7-238 + карте.

Драгичевић 2000: М. Драгичевић, Списи о западнијим српским говорима, Бања Лука, 5-120.

Драгичевић 2001: М. Драгичевић, Најзападнији српски говори данас, Зборник за српски језик, књижевност и умјетности, књига I, Бања Лука, 79-89.

Драгичевић 2002: М. Драгичевић, Судбина самогласничких секвенци у данашњем говору требавских Срба, Српски језик VII/1-2, Београд, 205-211.

Ивић 1956: П. Ивић, Дијалектологија српскохрватског језика (Увод и штокавско наречје), Матица српска, Нови Сад.

Ивић 1966: П. Ивић, О Вуковом Рјечнику из 1818. године, Београд.

Ивић 1994: П. Ивић, Српскохрватски дијалекти (њихова структура и развој) I књига, Издавачка књижарница Зорана Стојановића, Сремски Карловци - Нови Сад.

Ивић 1996: П. Ивић, О језику, Група аутора, Република Срска Крајина, Книн-Београд, 143-158.

Козомара 2000: Д. Козомара, Фонетске особине говора села Бастаса, дипломски рад у рукопису, Филозофски факултет Универзитета у Бањалуци. 
Козомара 2002: Д. Козомара, Млинарска терминологија Бастаса, Зборник за српски језик, књижевност и умјетност II-2, Бања Лука, $197-200$.

Николић 1991: М. Николић, Говори србијанског Полимља, Српски дијалектолошки зборник XXXVII, Београд, 1-549.

Окука 2008: M. Okuka, Srpski dijalekti, SKPD Prosvjeta, Zagreb.

Петрић 1961: M. Petrić, Geografski i historijski pregled, Glasnik Zemaljskog muzeja u Sarajevu, Etnologija, Sarajevo, 21-30.

Петрић 1961: M. Petrić, Porijeklo stanovništva, Glasnik Zemaljskog muzeja u Sarajevu, Etnologija, Sarajevo, 21-90.

Петровић 1973: Д. Петровић, О говору Змијања, Библиотека ЗФЛ XIV/1-2 и XV/1-2, Нови Сад.

Пецо 1978: А. Peco, Pregled srpskohrvatskih dijalekata, Beograd.

Рамић 1999: Н. Рамић, Ливањско-дувањски говорни тип, Српски дијалектолошки зборник XLVI, Београд, 263-426.

Рамић 2010: Н. Рамић, О јатовским изоглосама, Филолошко-уметнички факултет, Крагујевац, 1-134.

Црњак-Козомара 2015: О вокализму говора Јаворана, Српски језик XX, Београд, 697-710.

Чустовић 1961: Đ. Čustović, Narodni govor, Glasnik Zemaljskog muzeja u Sarajevu, Etnologija, Sarajevo, 91-117.

\section{THE FATE OF VOCAL GROUPS IN THE SPEECH OF BASTASI (NEAR BOSANSKO GRAHOVO}

\section{Summary}

Based on relevant examples, this paper primarily examines the ways of neutralization of individual vocal groups in the speech of a Bosansko Grahovo village. The paper aims to present the fate of vocal groups in the examined location and, based on the existing literature, determine its place in the western Bosnia Serbian speeches as a compact speech unity.

Key words: vocal groups, contaction of vocal groups, neutralization of vocal groups, Serbian and Iyecavian speeches of western Bosnia, east Herzegovina (Herzegovina-Krajina) dialect. 